From 'Good as Gold' to 'Gold diggers': Farming Women and the Survival of British Family Farming

Linda Price* and Nick Evans ${ }^{+}$

* School of Planning, Architecture and Civil Engineering Queen's University Belfast

David Keir Building

Stranmillis Road

Belfast

BT9 5AG

Tel: +44 (0)28 90974397

Email l.price@qub.ac.uk

+ Department of Applied Sciences, Geography and Archaeology University of Worcester

Henwick Grove

Worcester

WR2 6AJ

Tel +44 (0)1905 855187

Fax +44 (0)1905 855132

Email n.evans@worc.ac.uk

${ }^{+}$corresponding author 


\title{
From 'Good as Gold' to 'Gold diggers': Farming Women and the Survival of British Family Farming
}

\begin{abstract}
The survival of family farming in British agriculture has long been a topic of interest for rural researchers and is undergoing something of a current renewal of interest. However, insights from feminist approaches remain underutilised despite the crucial role farming women continue to play in family farming. This paper addresses the unity of farm, family and business by interpreting it as a patriarchal 'way of life'. An ethnographic-informed repeated life history methodology is employed to study in detail the family members of seven farms in rural midWales. Findings show that the recent survival of the family farms investigated has been heavily dependent upon compliance with a patriarchal ideology that demands women be 'as good as gold'. However, it is discovered that a new view of women is emerging in the world of British family farming, that of 'gold digger'. Women entering relationships with farming men are increasingly being considered a threat to farm survival by virtue of their entitlements if the relationship breaks down. The necessity to study the intricacies of personal relationships in family farming has important implications for most future research into this form of agricultural business arrangement.
\end{abstract}

\section{Women and Family Farm Survival}

The British 'family farm' has long been a source of research fascination for rural social scientists and agricultural geographers. Periodically, claims are made about the extent to which family forms of farming will disappear, backed by undeniable evidence of deep-seated structural change such as that indicated by the rapid decline of farm personnel. A host of factors have been suggested over recent years for the continued survival of the family farm, their nature tending to reflect the different theoretical approaches used in the analysis of the geography of agriculture. These are reviewed briefly in the first part of this introduction. One phenomenon associated with family farming that has received varying amounts of attention in different localities has been that of patriarchy. The effects of patriarchy on individual farm family members continue to be investigated, particularly in an international context (Brandth, 1994; Shortall, 2002), as discussed in the second introductory section. However, a direct relationship between family farm survival and patriarchy in Britain remains largely unexplored in recent times, hence the purpose of this paper. Analysis of this relationship requires a reengagement with insights from feminist theorisation. It is unfortunate that, since the mid1990s, work informed by feminism addressing the enigma of the survival of British family farming has rather stagnated. In the meantime, analyses of family farming, even those informed by new 'agri-cultural' ideas (Morris and Evans, 2004), have largely ignored the evidence for patriarchy and its continued importance to farm survival, a caveat best addressed through the adoption of a feminist critique. With these cultural and feminist lenses of inquiry, the paper subsequently uses examples from existing family farms to reveal how patriarchy influences the ability of family farms to survive.

\section{Changing Explanations of Family Farm Survival}

In the 1970s, attempts were made to describe the behaviour of farming individuals within farm family households, although this was largely divorced from the family context. Other work treated the family farm merely as an economic unit or as a social group within rural communities (Gasson et al., 1988). In this way, individual action, family relations and market relations were regarded as structurally distinct (Marsden, 1984). Only with the emergence of a modified political economy approach in the mid-1980s were these elements drawn together in a coherent way for analysis, with the 'family' becoming a unifying concept (Marsden et al., 1986; Bowler and llbery, 1987; Morris and Evans, 1999). One key question for those adopting a political economy perspective concerned why the family farm persists within capitalism when an 'evolutionist thesis' predicts the demise of family control over the factors of production. This approach was of great value as it effectively moved the farm family centre 
stage to consider more fully the activities of family household members, the extent of penetration of external capitals behind facades of 'family' ownership and the unevenness of corporate controls over family businesses. One particular avenue explored in the search for an explanation of farm family survival was the structural advantages of the family unit in relation to levels of engagement with non-agricultural activities. For example, the adaptability of the family business was examined through pluriactivity as an illustrative strategy for survival. However, the logic of the perspective was soon used to demonstrate that pluriactivity, such as on-farm diversification, offered external capitals another avenue of penetration into the family business (Evans and llbery, 1989).

Although political economy was modified in an attempt to provide a more satisfactory framework to explore family / work interrelationships, a point often ignored (see Marsden et al., 1996), it was not modified enough for some critics. Gasson and Errington (1993, p7.) neatly summarise this criticism in that:

'The tendency has been to treat the family farm in general terms, assuming it to be a nuclear family where relationships are based on sentiment, the pooling and sharing of resources and an egalitarian distribution of power. This approach takes for granted what needs to be empirically investigated and assumes that one particular configuration of kinship / household relations applies universally'.

Hence, the 'family' was often viewed as passive or as a 'black box', or else dismissed as an ideologically-loaded categorisation, within the 'grand theory' of political economy'. This was tempered by some consideration of individual farmer decision-making, a legacy of behavioural work in agricultural geography (Burton, 2004) and by engagement with feminist theory to attempt to make family and gender relations reappear into the 'field of vision' of those researchers adopting a political economy approach (Whatmore, 1991a). Even with claims made for 'post-structuralist' analysis from the mid-1990s, answers to the question of family farm survival have remained firmly focused on the influence of external capitals, labour arrangements and non-agricultural activities, with more cultural approaches largely nascent (Morris and Evans, 2004). A body of work is now beginning to emerge engaging with the symbolism and social context of agriculture, with behaviouralist influenced approaches also seeing something of a revival (see Potter and Tilzey, 2005 Winter, 2005). According to Winter (2005), this is partly a response to the need to provide evidence to support or refute a hypothesised 'post-productivist transition as a way to capture the current restructuring of British agriculture (see also Evans et al., 2002; Walford, 2003; Roche, 2005;). Indeed, Burton has begun to explore 'the symbolic importance of productivist activity in farmers' self-identity' (Winter, 2005, p.614), helping to define 'productivism' in farmers as a more logical starting point for any analysis of supposed 'post-productivism' than some other research work that has appeared on this topic. Such work contributes to reversing the neglect of the agency of farmers by revealing the socio-cultural dimensions of sustainable development in agriculture (Winter, 2005). Unfortunately, difficulties continue to lie ahead for such approaches if familial relations are not fully worked out to establish exactly who is 'the farmer' before behaviouralistderived techniques are applied. Re-engagement with a feminist critique, as exercised here, immediately suggests that the spokesperson for all the individuals hidden behind the family façade remains implicitly male. For example, even in Burton's (2004, p.366) timely reassessment of the behavioural approach, the ability of farm women to undertake work appears as a separate factor in the 'perceived behavioural control' of 'the [male] farmer'.

\section{Farming Women and Patriarchy}

International geographers have been more consistent in their engagement with feminist theorisation than those in the UK, focusing especially on issues of identity (for a review, see Brandth, 2002). In Norway, researchers using a structural feminist perspective reveal the necessity for patriarchy to be built into global capitalism because it touches the ground within locales and affects the micro day to day actions and lives of farming individuals (see McDowell, 1999 for a theoretical discussion). Such critiques have evolved to highlight the importance of tracking the formulation and maintenance of gender identity and relational masculinity and feminity in explaining the geographies of gender identity (see Almas and Haugen, 1991; Brandth, 1994; Brandth and Haugen, 1997). This work has revealed both farming men and women's stubborn adherence to patrilineal gender roles. As Brandth (2002) 
crucially demonstrates through analysis of individual interview and focus groups material, the patriarchal discourse or frame of reference of family farming is hard to resist when it encompasses so much of the past, present and future of an individual.

Other commentators (Pettersen and Solbakken, 1998; Shortall, 2002) have interrogated the extent to which individual empowerment emerges as a result of the multiple gender roles required for farm families to implement adjustment strategies and restructure their businesses. However, this mode of power is limited to decision-making within a tightly constrained gender position, as demonstrated by Evans and llbery (1996). A more radical feminist interpretation points towards farming women further retrenching behind the ideology of family farming. As Teather (1994) has demonstrated through qualitative case study work in the Australian context, farm women may actively allow their farming gendered identities to be exploited in order to resist threats to the family farm's survival from agribusiness. This exploitation, as Heather et al. (2005, p.94) affirm, means that the 'struggle for survival is not a time for self-actualization', despite the women in their Canadian study being aware that 'restructuring has human costs' ( $p .86)$. This brings us to a position where an adherence to patriarchy can be viewed as insulating the farm family from the full effects of capitalism, yet like capitalism it is highly exploitative of its members. Put simply, British family farm survival relies on an adherence to farming identities which are relational and patrilineal. The unity of farm, family and business continues to be underestimated by analytical separation of the concepts. At one time, in the early 1990s, there seemed to be advantages in using the term 'household' to infer wider consideration of the family beyond the 'principal decision-maker' (the 'farmer'), but it has rather become a 'catch all' term (see Chaplin et al., 2004 and Meert et al., 2005 for examples of the way in which household continues to be used as a unit of analysis to explain farm survival).

To summarise, considerations of farming women identifiable within a British family farming 'survival' theme undoubtedly remain influenced by political economy work in agriculture. For example, research has examined the importance of farming women's contribution to the farm economy from a policy perspective (Parsons, 2001; Monk, 2002) and the potential impact pluriactivity may have on gender relations and issues of power (Evans and llbery, 1996). The work of Gasson (1990 and 1992), from an agricultural economics perspective, regarded spouses and farmers' wives as the 'hidden workforce' of the family farm business. Further, Whatmore (1991a) critically revealed the importance of women's reproductive activities in maintaining the farm's survival. She moved conceptualisation forward by exposing the patriarchal nature of British patrilineal family farming. This was achieved through a theorisation of productive and reproductive circuits. However, a consideration of women's roles remains closely allied to the analysis of the farm economy. Yet, unanswered questions remain concerning why farming women are prepared to undertake the double or triple burdens of on-farm (inside and outside) and off-farm work and the personal toll of such burdens (see Price and Evans, 2005).

\section{Examining the Survival of a Family Farming Way of Life in Powys}

This paper argues that farm, family and business unity can be more appropriately viewed as a lifestyle, or a 'way of life' (see Bennett, 2005; Price and Evans, 2005; Heather et al., 2005) which amalgamates the historical, cultural and economic facets of family farming within one patrilineal ideology. Adherence of family members to the patriarchal way of life is so crucial that it is relevant to explore family farm survival as a function of it. For example, when women demand their own farming business and partnership rights, the structure of family farming can become disrupted and survival along traditional lines may no longer be possible (see Mackenzie, 1980, 1992a, 1992b and 1994 for examples within a Canadian context). Certainly, the women in Heather et al.'s (2005) study were aware of this and retracted greater demands for farming women's rights in favour of patriarchal structures embedded in a valued way of life which to their minds helped ensure farm survival. The threat is clear. If women refuse to be 'as good as gold', the farming way of life becomes vulnerable to disintegration and survival of the family farm is jeopardised. 
It emerges from work to date that farming women play a pivotal role in the survival of British family farming. Yet, this 'way in' to the explanation of the extraordinary resilience of family farming has been under-researched. Adherence to a patriarchal 'way of life' integrating farm, family and business demands investigation. It is inadequate merely to describe women's labour activities, for example, without asking three crucial questions:

(i) how / why do they comply with a patriarchal way of life?

(ii) what are the patriarchal relationships and emotions that bond them to certain modes of behaviour within a familial context?

(iii) what are the implications of compliance and can the family survive in farming if women challenge a patriarchal ideology?

This paper attempts to contribute some answers to these key questions. A feminist theorisation assists a focus upon the extent to which the changing nature of women's relationship to the patriarchal ideology of family farming is influencing survival of the family in farming. Simultaneously, the need for culturally sensitive research to access this changing relationship demands the application of an appropriate ethnographic methodology which is now detailed.

It was clear at the outset of the study that the standard questionnaire format used in most agricultural geography research, even with the inclusion of a predominance of open-ended questions, would fall into 'the farmer' caveat identified earlier. Rural geography generally has witnessed an explosion of interest in ethnographic methods (Hughes et al., 2000). However, despite Gasson (1973) identifying many years ago the importance of peeling away the subjective layers of values within family farming, agricultural geographers have been slow to develop the more qualitative types of methodology. For this study, an ethnographically founded repeated individual life history methodology was devised and utilised. Brandth (1994) used life history interviews to study the construction of gender as a relational process between men and women farmers in Norway. However, researchers have seldom availed themselves of the opportunity to return to the farm on more than one occasion (or perhaps two occasions in the case of longitudinal work), the work of Pile (1991) some time ago being a notable exception (Morris and Evans, 2004).

Four distinct advantages to this methodology can be identified.

i) It is able to cope with the fact that farmers are not one homogenous group (see Morris and Evans, 1999), specifically by questioning more than one member of the farm family.

Structured or semi-structured questionnaires have formed the basis of most knowledge from research in the sub-field of agricultural geography, yet a fundamental flaw in much of this work is that the actual position of the individual questioned who is taken as 'representing' the family farm business is rarely made explicit.

ii) It allows participants to focus on their decisions, life stages and perceptions of their lives. It is appropriate in getting 'below the surface layers of facts and reasons, to the underlying layers of feelings, values and processes' (Ni Laoire, 2000, p.85). This aids the mapping out of subjective behaviour and the identification of experiences and emotions incorporated within a family farming way of life.

iii) It enables participants to explain their lives in their own terms, reflecting on their activities and revealing how they see themselves as individuals. It is inadequate merely to reveal the multiple roles that men and women enact in developing a gendered understanding of the way of life without consideration of how they diminish, disguise or reify the importance of these roles. In their study of an American North-west farming community, Anderson and Jack (1991) discovered that women described their hard, manual farm labour as merely "helping out'. Through life histories, participants could discuss what this term really meant to them from day to day. Scott (1993 and 1996) found that farming women in Kentucky also underplayed the importance of their multiple roles in the maintenance of a viable farm business.

iv) The innovation of repetitious life history interviews allowed the confidence of interviewees to grow, deeply personal matters to be discussed and, ultimately, conflicts with an 'idealistic' family farming way of life to emerge. The importance of listening and unwrapping the ambiguity of certain familial phrases and words was heightened as the process proceeded (see Anderson and Jack, 1991; Scott, 1993). The participants felt able to discuss their hopes and worries, unhappiness and feelings of being trapped or invigorated by their way of life. 
The evidence presented is drawn from seven case study farming families located in Powys, Mid-Wales, who serve to capture some of the diversity of this agricultural business arrangement within the county. Powys is a predominantly upland farming area dominated by grass-based, low output, small family farm enterprises (Welsh Agricultural Statistics, 1999). Further, it has been found by Hawton et al. (1998) to have the highest rate of farming suicide in England and Wales, which must be seen as the ultimate destruction of individual identity, often leading to the disintegration of farm, family and business and, therefore, the implosion of the family farm itself (see Price, 2004). The farm family unit in this locality is clearly under pressure and this provides an objective rational for selection (see Kelly et al.,1995 and Kelly and Bunting, 1998 for further statistical information). The researchers also drew upon a cultural background within Powys to identify key gatekeepers, such as livestock auctioneers, who could speak to potential participants and ask permission for use of their contact details. Selected farms ranged in size from a tenanted farm of 24 hectares to a multiple site owneroccupied holding of 384 hectares. The farms were geographically dispersed throughout the county and varied in the dominant type of agricultural husbandry they practiced.

The fieldwork took place over a nine-month period in 2002. Group interviews were initially conducted with all members of the farm families, not all of whom were necessarily related through blood ties. The ages of those taking part ranged from 12 to 80 years of age.

Following the introductory session, four rounds of interviews were subsequently carried out at times convenient to the 26 participants. Each session notionally addressed a different 'theme' with the participants (such as growing up, work roles, farming systems) as a way to break the ice and to set them thinking in anticipation of the next visit. The emphasis was always upon allowing participants to talk about the issues important to them within these loose bounds. On average, each interview lasted two hours, often conducted late in the evening to fit into the busy farming schedule. In quantitative terms, the case studies generated 120 detailed interviews. Where appropriate, the interviews were tape-recorded but extensive notes were always taken during the interview itself. Supplementary observations were made immediately after the end of the interview. It should be noted in the subsequent discussion that the names of family members have all been changed with their agreement to protect their anonymity. For ease of reference, Table 1 shows how those characters reported in the analysis are related to one another.

\begin{tabular}{|c|c|c|c|c|c|c|}
\hline Farm & $\begin{array}{c}\text { Father } \\
\text { (M) or (W) }\end{array}$ & $\begin{array}{c}\text { Mother } \\
(\mathbf{M}) \text { or (W) }\end{array}$ & $\begin{array}{c}\text { Male } \\
\text { Farmer }\end{array}$ & $\begin{array}{c}\text { Farming } \\
\text { Woman }\end{array}$ & Son & Daughter \\
\hline $\mathbf{1}$ & --- & --- & John & Dilys & Dilwyn & 1 \\
\hline $\mathbf{2}$ & --- & --- & Rhodri & Beth & --- & Eleri \\
\hline $\mathbf{3}$ & --- & --- & Wynne & Shan & 1 & --- \\
\hline $\mathbf{4}$ & Alun (M) & $\begin{array}{c}\text { partner } \\
\text { present (M) }\end{array}$ & Geraint & Mair & 1 & 1 \\
\cline { 4 - 7 } & & --- & Ithel & Catrin & 1 & 2 \\
\hline $\mathbf{5}$ & --- & Huw & Gwen & 1 & 1 \\
\hline $\mathbf{6}$ & Gareth (M) & Alvine (M) & Jack & Carys & --- & 2 \\
\hline $\mathbf{7}$ & --- & --- & present & Megan & 2 & 1 \\
\hline
\end{tabular}

'Male Farmer' identifies the main operator of the farm business on a day-to-day basis but is not necessarily the 'principal decision-maker' nor head of household.

(M) refers to father or mother of Male Farmer.

(W) refers to father or mother of Farming Woman.

All names are fictitious. Not all relations (participants and non-participants) in the research are identified, just those mentioned in this paper.

Table 1: The main characters reported in the empirical evidence.

From the information obtained, it became possible to chart individual behaviour within the overall gender dynamics of the family farm. Three themes emerged, each of which are now subsequently explored in detail. First, there is clear evidence amongst families for the early 
planning of 'survival' as part of an intricate generational transfer process. A preference emerges for women who can enter a farm family with a dowry. Second, once enrolled in the family farm, there is a requirement for farming women to be 'as good as gold', frequently manifest by them not exercising fully their legal rights within the farm business. Third, a new twist to familial farming gender relations is discovered, captured as a movement away from farm women being 'as good as gold' towards an exposition of them as 'gold diggers'. Far from ensuring the continued existence of the family farm through compliance, there was strong recurrent reference to the way that young farm women threatened survival. This new conception was expressed to the point where it revealed itself to be a major source of fear for the future amongst both farm men (particularly) and women.

\section{Dowries and Farm Family Survival}

The interviews indicate that that there is a strong patriarchal gender ideology underpinning the traditions of agriculture, reinforcing the findings of Bennett (2004), Brandth (2002) and Shortall (2002). For example, all but one of the eleven female participants described themselves as coming to live on their husband's or partner's farm, or his 'home' (McDowell, 1999), upon the maturation of a relationship. Further, continuing patriarchal spheres of dominance and operation within the farming home mean that the geographies of gender identity operating there remain gender segregated despite the lack of spatial separation of home and work, highlighting once again the unity of farm, family and business.

The general adherence to patrilineal gender spheres of operation apparent in the research can partially be explained by evidence supporting the continued existence of dowries within the family farm system. Research on dowries, revealed in the work of Gasson and Errington (1993), has not since been taken up to highlight the difficulty farm women have in avoiding collusion in patriarchy. Women in the study generally felt that they were unable to challenge a dowry system that brought some benefits to them (Shortall, 2002). This system confers benefits to sisters and daughters but also a responsibility to maintain the patrilineal status quo. As Alun reveals, "I had four sisters. They had monetary gifts from the farm on marriage". Alun goes on to admit that "there was never any question that I, as the only son would be successor - that's just the way it was". Even one generation later, Alvine's daughter received "money from the farm when she got married" despite marrying out of farming. Gwen also reveals, when referring to her sister-in-law's recent marriage to a non-farmer, how "it seemed like Huw's dad [Gwen's father-in-law] was very generous when she got married". Implicitly, this generosity disarms any protest from Alvine's daughter or Gwen's sister-in-law to the male inheritor and demonstrates how the enactment of patriarchal norms perpetuates the family farm 'way of life'.

Several of the women brought up as 'farmer's daughters' moved from one patriarchal farming arena dominated by their father to that of their spouse's paternal family. As Gwen, in her early forties, confirmed "Huw and I are the same status. I left home with something to bring with me. I didn't think about coming to his home - it's just the way it was". Alvine, in her late 50s, also acknowledged "I had money from home when I came here - but I never expected to have much of a say in the business". Alvine qualifies this position when she comments "We get on together here. I haven't been pushed out. My thoughts have come into it". But, Alvine admits that in reality "my husband usually gets his own way in business decisions - there's no point in rocking the boat". This 'rocking the boat' would involve an exertion of power that would threaten the patriarchal structures and thus the survival of the way of life itself. What Alvine and Gwen both feel is that they wouldn't change their way of life, that farming is 'in the blood' and that being a 'farmer's wife' gives them a 'culturally superior' status to enjoy.

Astonishingly, the fieldwork indicates that the culture of agriculture leads farming sons to be aware that marrying the daughters of farmers already indoctrinated into patrilineal practices yields potential advantages. Young women who have internalised the farming 'way of life' ideology as 'superior' are more likely to ensure farm survival through their compliance. As Geraint says of his wife, Mair, "Well, she knew what she was getting into". This is reaffirmed by farm women themselves, as with Dilys, in her forties, who claimed "All I wanted to do was stay in farming". Alun, the one respondent who has experienced divorce, partially blames his 
divorce on the fact that "My ex-wife was a city girl. I should have known she wouldn't take to it. My friends, who married farmers' daughters, they've got on well. They're practical women, turn their hands to anything". Alun's experience of his ex-wife's attempts to obtain a high divorce settlement is interpreted by him to be indicative of her lack of understanding of the "...poverty of the way of life. The money all goes into the farm, never the individual".

Dowries evidently take many forms. They can be pay-outs to daughters from the paternal farm on marriage, or gifts of land, stock and even, when no male heir exists within the daughter's family, entire farming units. What is crucial to patrilineal farm survival is that women allow assets from these dowries to be subsumed within that of their husband's family upon marriage. For example, Megan, also a General Practitioner, reveals that "My parents were grateful to have someone educated, supportive and respected to carry on the farm". Megan's husband controls the land and Megan accepts this as part of a "... farming way of life - it involves your whole life".

What these results demonstrate across all the farm types, locations and ages of participants is that the female participants are expected to enter the maturation of a relationship with money, assets and an adherence to a patriarchal way of life intact (for a description of way in which heterosexuality is essential to this system, see Little, 2003). It was startling that even Eleri, in her teens, felt that "I want to stay in farming so l'll probably marry a farmer". The issue that she is already a farmer does not appear to have entered her consciousness. Her socialisation as a 'farmer's daughter' has evidently prepared her for the acceptance of the patriarchy inherent in such a system. This compliance has become ever more crucial if family farming is to survive given the rapid decline in farming incomes the participants have experienced as a result of restructuring of the agricultural industry since the late 1980s. In Powys, the impact of the 2001 Foot and Mouth crisis is making this survival particularly difficult (see Scott et al., 2004). If women reject this subsumption of their capital within their spouse's business, or were to attempt to use it for their own purposes, the farm's survival becomes compromised. The use of dowries has become an essential ingredient to combat declining farm incomes and prepare the business to accommodate new family members. Alvine reiterates many of the participants' comments when she says that "There's only enough income in farming for one person now".

\section{Survival and the Suppression of Farm Women's Legal Rights}

Apart from necessitating a willingness of farm women to resist utilising their own financial assets, the patrilineal nature of British family farming survival also requires the suppression of legal entitlements. The patriarchal farming way of life and traditional mode of patrilineal inheritance can only survive if women voluntarily give over legal control of their capital to their spouse's family or are prepared to remain silent partners in the farm economy. Ashton (1991) drew attention to this situation, although this generated little further research interest (for a recent exception in a Canadian context, see Heather et al., 2005). Since this time, it appears that just retaining the family farm in business has become so difficult for the participants that the championing of women's own legalities has become subsumed within the larger battle to save the cultural historicity of the family farm.

Clearly, then, an attachment to a particularly resilient patriarchal 'way of life', reinforced through a British legal inheritance system dominated by primogenitor, is crucial for farm survival (Grace and Lennie, 1998). In fact, spousal legal partnerships in Less Favoured Areas like Powys (see National Assembly for Wales, 2003) are now less likely because upland agricultural policy has moved from a headage support system, which allocated numerical payment limits associated with livestock animals to individual 'farming partners', to an areabased one (the Hill Farm Allowance). The switch in 2005 to a Single Farm Payment seems to reaffirm that there is little incentive for farm businesses to move towards including farm women in their legal structures as the amount of subsidy payment moves from a calculation based on historic receipt to one based on the land area farmed ${ }^{2}$. Further, there has been a loss of tax advantages in having wives as legal partners. 
The evidence from Powys reveals that the female participants in the study are only required as 'partners', albeit compliant ones, when policy impacting upon the agricultural sector yields an economic advantage for the farm. None of the female participants under fifty were technically legal partners in the farming business, indicating the lack of current importance of partnerships to the farm economy. As Alvine says, "When I got married, I became a partner I didn't think about it". Her husband Gareth notes that historically "It was natural to have husband and wife partnerships". But, Alvine still says "I didn't really expect to have much say in his business though [one to which she contributed financially through the dowry system], although I haven't been left out". As Gareth confirms, "It's what our accountant advised us to do for tax reasons". However, female participants, such as Dilys, who work full-time on the farm could give examples of where "He [her husband] always has his own way in the end".

Examples such as this demonstrate how women's wishes have not entered into farm business thinking, have been ignored or have not been exerted despite a legal entitlement to exercise decision-making powers. Even Beth, in her early fifties, who farms with Rhodri on a tenant farm, confirms "The tenancy's in his name" with Rhodri (rather smugly) admitting "I've got it for life". Without Beth's compliance, the farm could not survive. As Beth says, the farm “... wouldn't keep us both if we wanted the wage most people expect - I try not to spend farm money". For younger couples, such as Ithel and his wife Catrin, in their thirties, there is no direct benefit to them of farming in partnership. Catrin says "I moved to Ithel's farm". But Catrin still works off-farm to supplement 'his' farm and business because as Catrin comments "We love the way of life - and want to keep it going for our son". Considerable literature exists which highlights the necessity of women's on- and off-farm work to the farm's survival (Price and Evans, 2005). Nevertheless, the reasons women do this, or the repercussions to farm survival if they cease to do this, have been under-researched. The findings here demonstrate that women are most likely to adhere to such a way of life only when they revere it as 'cherished' and 'superior' within the rural locale (Little and Panelli, 2003; Price, 2004).

The interviews demonstrate that only when agricultural policy and the taxation system make it rational and worthwhile for women to be partners are they incorporated (see Delphy and Leonard, 1992; Wallace et al. 1996; Whatmore, 1991b). Even this seemingly greater position of power is compromised by the condition that demands women to be relied upon to remain silent partners and not extract the funds to which they are entitled. To do so would be to threaten family relationships and the business which is sustained through the exploitation of relational ties. Alvine demonstrates such compliance by saying of her husband "Well, he never complains if I want a new dress or something - but then I'm not very extravagant and I try not to use farm money [to which she is entitled] if I can help it". Older farming women, such as Alvine, Dilys and Beth, are often reluctant to use 'farm money' and feel that they have to account for personal use of farms funds because their primary duty is to aid the farm's survival. Younger farm women must sign up to this ideology to benefit from those desirable aspects of a farming way of life. This is sometimes extended to participation in on and offfarm work to supplement a farm over which they have no legal tenure. Crucially, they must remain comfortably within familial relationships, and indeed commonly provide the glue for the unity of farm, family and business. However, questions arise about the repercussions that occur if women do not adhere to, or are even perceived not to conform to, this ideological suppression of their entitlements. It is to this issue that the paper now turns.

\section{'Gold Diggers' - A New Threat to the Survival of Family Farming}

There is little doubt that research on the importance of women within British family farming has progressed significantly over the last two decades. This has included efforts to recognise the crucial work that they contribute as farmer's wives (Gasson, 1992), expositions of gender relations in family farming (Whatmore, 1991a; Evans and llbery, 1996) and culturally-informed work on the representation of farming women where the 'farmer's wife' has been reified as the ideal version of 'the woman' within the rural idyll (see Little and Austin, 1996; Morris and Evans, 2001; Bennett, 2005). Such research has certainly contributed to an understanding of why family farms remain in business, a key concern for political economy based analyses. What suffers from a lack of emphasis, however, is the imperative for compliance of women that is demanded by family farming. If younger women, in particular, reject the patrilineal 
ideology bound to family farming illustrated earlier in this paper, then the survival of the farm can be thrown into doubt. British family farming depends, therefore, on personal patriarchal relationships working, or at least continuing to exist.

Of all the farming people participating in this study, it is Alun who has experienced the breakdown of a relationship primarily as a result of his ex-wife refusing to take on a compliant role. His case provides a stark example of how non-compliance almost led to the demise of a family farm. Alun, now divorced, claims "She never wanted the farming way of life. Thank goodness she was never a partner in the farm". Alun was just able to hold onto the farm, despite a large pay-out to his ex-wife, partly through early transference of the business (perhaps on paper more than in operational reality) to his two sons. Having become sensitised to this possibility, he could recount instances where men had been thrown into despair, contemplating suicide, when faced with divorce and the disintegration of both the farming unit and their way of life. Alun is vociferous in his comment that "Too many women coming into farming are gold diggers now". His ex-wife worked off-farm and undoubtedly subsidized their day to day living with her off-farm income, but this was unrecognised by Alun during their divorce settlement. Alun believes that "She was my wife, but she had no right to anything from the farm. l've passed it over to my sons. She would have ruined me if she could". Even Alun's son, Ithel, reinforces this position by saying "The divorce could have cost us everything but luckily it has all worked out for the best - we couldn't lose the farm". Alun views the successful inheritance of the farm by his sons as evidence that he has fulfilled his part in his family's farming survival history. Patrilineal succession, therefore, remains a sign of the success of such a patriarchal ideology to reproduce itself.

Patrilineal succession remains one of the key features of British family farming. It is not only dependent upon the existence of sons, but also women's willingness for their son's and brothers to inherit what is largely, in fact, wealth to which they are legally entitled. In the Powys case studies, new tensions were being exhibited as a result of an increasing lack of trust demonstrated in women moving forward, often from a previous position as a 'farmer's daughter', through the maturation of a relationship with a male, farming partner (spouse). This fear is justified and articulated by the participants in terms of keeping the farm 'safe' for future male heirs. As John says, "women can come in and take half of everything. It's happened around here. We, as parents, have to try and safeguard the farm for Dilwyn". Dilwyn is only 13 years of age but already his father is concerned that a wife could threaten the future of the farm. Dilwyn exhibits an awareness of this situation by commenting during the conversation that "I'm never getting married then".

Interestingly, this fear is not just a male preserve. Mothers across the generations are equally concerned that their son's estate is protected from women, a reflection of their own patriarchal indoctrination and compliance. As Gwen says, referring to her seven year old son, "You need to marry from within farming, otherwise they [women] haven't got a clue". Gwen draws upon her local knowledge of the increased preparedness of women to divorce farming husbands to say "I know auctioneers locally who've said it's made them sick having to go in and value a farm for divorce - it'll have to be sold - it's not right". Both farming women and men were vocal in their distain of a newer generation of women coming into farming who, Alun perceives, "... are threats to succession. Land values have rocketed in relation to what you can do with it. They no longer play the game". Alun continues "It's the best business to be in! Marry a farmer, then divorce and take half. Real gold diggers". The research reveals "gold diggers' as an emerging term in family farming parlance. It reflects the lack of trust in women to play the patrilineal way of life 'game', thus jeopardising family farm survival.

Gareth, in his early seventies, is contemplating retirement and transference of the farm to his recently-married son. He provides an example of the real threat younger women now pose to patrilineal succession and farm survival by saying "The issue of succession is uppermost. I have to manage the succession - see how things work out. Women can threaten the farm, you know". This subject occupied Gareth's thoughts during many interviews and was causing him obvious distress. His wife, Alvine, also articulated the same fears by considering neighbouring farms and saying "It happens, you know. A wife comes in, the farm's passed over and then she decides she doesn't like it and divorces taking half the farm. All that hard work of generations - up in smoke". 
Clearly, the willingness of younger women to end unhappy relationships through divorce is reflecting divorce patterns more generally in society (see Abbott and Wallace, 1997). The results reveal how the fear of this trend is now affecting the familial relationships within family farming, actively weakening firmly established modes of succession and inheritance as a result. Previously, it was essential that fathers had built up trust in their sons before they would consider handing over ownership of the farm (Gasson and Errington, 1993). In livestock areas such as Powys, one indicator of acquired farming skill was care for a particular stock line on the farm that had been developed over generations (Gray, 1998). However, succession is now being delayed by older men, such as Gareth, because of the additional fears presented by 'gold digging' women entering the family. The title embedded in the future male inheritor as son and prospective inheritor, therefore, is being retained longer than ever. One consequence is ensuing frustration and impotence at exercising decisionmaking power experienced by younger farming men such as Jack, Gareth's son. Jack admits that "I'm fed up being treated as the kid - never allowed to make decisions. He [Jack's father] is going to have to let go sometime. then I can farm how I want to". Jack is married to Carys, herself a 'farmer's daughter'. She is aware that "I'm being treated with suspicion. I suppose they [her in-laws] think I was after their son's money just because I was pregnant before we got married". Carys goes on to say "but l've done an accounting course. They won't be able to pull the wool over my eyes". The amount of suspicion, even to the extent of paranoia, linked to ensuring the farm's survival is now palpable. Sons are experiencing lengthier 'apprenticeships' before they inherit and the evidence here suggests that they are beginning to internalise the rationale behind this delay. Thus, Ithel, in his early forties, confirms that "Too many women are gold diggers and the older generation is less willing to pass the farm on".

Perhaps a more radical solution to delaying farm succession is also evident in Powys, that of attempting to ensure family survival on the land through non- marriage. It seems incredulous that in a 'traditional' farming locality such as Powys, parents are actively discouraging their sons from marrying and encouraging them to live together instead. This is especially so as there are likely to be problematic discussions associated with children born of such relationships in terms of 'keeping the family name on the land'. Nevertheless, this is a trend which has entered onto the canvas of family farm relations. Ithel notes how "Parents are discouraging marriage and I could give you the names of men my age who are taking out prenuptial agreements - but they won't stand up in court". He continues "There are a lot of owner-occupiers in Powys, so there's a lot of money's-worth if you own your farm outright". Ithel's wife Catrin is equally disparaging of women her age. She can name those who received large settlements from a farm on divorce, saying "It's not right - is it?" A contradictory tension thus emerges from the case study evidence. Women are required to ensure the survival of family farming, to produce male heirs, to work on and off the farm to supplement farm income, yet simultaneously they are being re-imagined as a major new threat to the whole 'way of life' family farming ideology. The system is at risk of collapsing as relationships between men and women change, suspicion pervades and disintegration, through divorce, becomes a reality.

For the case study farm families, the fear of changing forms of intra-familial farming relationships has become a new reality amongst this traditionally conservative group. Shan and Wynne, two participants, remain unmarried and the implication is that, with Wynne's mother having money and so background influence in the farm, it is safer for them to remain unmarried. As Shan says, "It's Wynne's farm. The bank manager said it was better for him to buy it on his own". Shan calls herself a farmer's wife, but she is aware that "Documents don't reveal the intricacies of family relationships and there's always been a huge envy of people owning property". Shan's partner Wynne plays down any family disharmony. He does say wryly, "Well, the mother-in-law [his mother] is always a difficult person to please". Wynne highlights how "Parents will hang on to the land 'til they die". In a later interview, Shan reveals how "I would have liked me and Wynne to have got married and bought the farm together". It can be suggested, therefore, that non-marriage and pre-nuptial agreements are emerging as new strategies for family farm survival to deal with the fear of women not complying with the patriarchal ideology bound up with family farming. 


\section{Conclusions}

The Powys ethnographic case study material demonstrates many points at which the ideology of patrilineal British family farming 'way of life' is fracturing. Farm survival is found to be heavily dependent upon socialisation within the ideology of family farming and the necessity for individuals to adhere to its gendered, patriarchal components. Disintegrating gender relations emerge as one major new threat to family farm survival. Within this overall theme, it is possible to draw three specific conclusions from the Powys material.

First, it is familial relationships in which farm women are 'as good as gold' rather than 'gold diggers' that aids in keeping family farming intact. Against this, suspicion now pervades attitudes towards women within the patriarchal ideology of the farming way of life. A new finding is the remarkable degree of consistency with which a discourse about women as 'gold diggers' has become established across the diversity of farm families and their members investigated. The research suggests that even women from farming backgrounds are being treated with distain and suspicion when entering personal relationships with 'farming sons'. Given that the farming way of life ideology relies upon compliance of the majority of its members, such suspicion is likely to encourage the results that are dreaded; the implosion of familial relationships and the ultimate destruction and disintegration of the family farm. The strength of this new threat to survival, real but especially imagined, must be factored into any assessments of farming futures.

Second, following on from above, the nature of inheritance and succession on family farms is being actively changed by the threat of women as 'gold diggers'. It is no longer adequate to ask male farmers simply about their intentions to pass a farm business onto one or more heirs as this is superficial without exploring the most influential factor - their attitude towards women. There is firm evidence from the case studies that fathers are postponing transference to identified inheritors (sons). The consequences identified in the research, which limitations of space prevent elaboration here, include the postponement of retirement amongst farming men; a move towards a more incremental approach to succession; damage to the mental and physical health of older farmers staying in charge for longer; and the distress of younger farming men as they experience frustration at the increasing length of time they are remaining 'sons' or prospective inheritors.

Third, many individuals are staying within unhappy personal relationships because they are aware that not doing so risks the survival of the family farm. This is an untenable position for personal fulfilment and happiness and undoubtedly places additional strain on family members. This said, familial ideology may act as a brake on personal choice, but divorce is becoming more prevalent within family farming. The impact on individuals of divorce within family farm contexts is largely uncharted territory. This research hints that women leaving the family farm set-up do so to the detriment of relationships with their children, wider family and rurality. Further, women must be only too aware of the repercussions to any son's inheritance if they, as mothers, are branded as the cause of the farm's demise. Such a realisation highlights how crucial it is that researchers acknowledge the importance of familial relationships when assessing the formulation of family farm business strategies, decisionmaking and, of course, the prospects for survival. Examinations of such relationships cannot be excluded, providing as they do the unity between farm, family and business.

The Powys case study findings reveal the overall importance of unifying farm, family and business in future conceptualisations of the survival and reproduction of British family farming. There is clearly value in incorporating insights from feminist theorisation when dealing with the cultural package that is the British farming family. As Winter (2005) has observed, there has been a resurgence of interest in research focusing on the 'agricultural household' and 'agricultural restructuring' strategies (Chaplin et al., 2004; Johnsen, 2004; Lobley and Potter, 2004). These papers all acknowledge that pluriactivity and diversification are part of attempts to maintain the farm's survival in a broadly 'productivist' sense through the endeavours of family members. Another recent body of work, critical of the conceptualization of the term 'post-productivism' (see Roche, 2005; Walford, 2003; Winter, 2005), also attempts to engage more with a socio-cultural embeddedness of 'farmer' decision-making within restructuring debates. The findings from Powys are important in demonstrating that such analyses, and 
thus understanding, will remain partial in the absence of a consideration of gendered relationships. This study has demonstrated their fundamental influence on family farm survival and thus the strategies 'households' and 'farmers' adopt. Public performances of farming gender identities seem all too often to be observed by researchers, obscuring the realities of a patriarchal family farming way of life. More culturally detailed ethnographies, as attempted here, can expose the importance of familial relationships and the pressure farming individuals are experiencing.

\section{Notes}

${ }^{1}$ It is of course acknowledged that other forms of farm business exist in Britain, ranging from single proprietorships where the business principal has no familial ties to corporate forms of land and farm business ownership. Farm family business ownership, where principal operators are related by blood or marriage, are reported consistently as controlling a high percentage of farms in the UK, typically in excess of $90 \%$ (see Gasson et al., 1988; Gasson and Errington, 1993) and so justifiably form the focus of attention in this paper.

${ }^{2}$ Where farm businesses are run separately by farm men and women, there may be some administrative advantages to moving to 'partnerships' so that only one set of SFP paperwork has to be completed. However, such cases would technically count as a merger of farm businesses and could be viewed potentially as eroding the business influence of farm women.

\section{References}

Abbott, P. and Wallace, C. (1997) An Introduction to Sociology: Feminist Perspectives (London: Routledge).

Almas, R. and Haugen, M. (1991) Norwegian gender roles in transition: the masculinization hypothesis in the past and in the future. Journal of Rural Studies 7 (1) pp. 79-83.

Anderson, K. and Jack, D. (1991) Learning to listen: interview techniques and analyses. Pp.11-27 in S. Gluck and D. Patai eds, Women's Words: the feminist practice of oral history (London: Routledge).

Ashton, S. (1991) The farmer needs a wife. Pp.122-139 in J. Aaron, T. Rees and S. Betts eds, Our Sisters Land: the changing identities of women in Wales (Cardiff: University of Wales Press).

Bennett, K. (2004) A time for change? Patriarchy, the former coalfields and family farming. Sociologia Ruralis 44 (2) pp. 147-166.

Bennett, K. (2005) The identification of farmer's wives: research challenges in the Northern Fells, Cumbria. Pp.60-75 in J. Little and C. Morris eds Critical Studies in Rural Gender Issues (Aldershot: Ashgate).

Bowler, I. and llbery, B. (1987) Redefining agricultural geography. Area 19 (4) pp. 327-332.

Brandth, B. (1994) Changing femininity: the social construction of women farmers in Norway. Sociologia Ruralis 34 (2-3) pp. 127-149.

Brandth, B. and Haugen, M. (1997) Rural women, feminism and the politics of identity. Sociologia Ruralis 37 (3) pp. 325-343.

Brandth, B. (2002) Gender identity in European family farming: a literature review. Sociologia Ruralis 42 (3) pp. 181-201.

Burton, R. (2004) Reconceptualising the 'behavioural approach' in agricultural studies: a socio-pyschological perspective. Journal of Rural Studies 20 (3) pp. 359-371.

Chaplin, H., Davidova, S. and Gorton, M. (2004) Agricultural adjustment and the diversification of farm households and corporate farms in Central Europe. Journal of Rural Studies 20 (1) pp. 61-77. 
Delphy, C. and Leonard, D. (1992) Familiar Exploitation: a new analysis of marriage in contemporary societies (Cambridge: Polity Press).

Evans, N. and llbery, B. (1989) A conceptual framework for investigating farm-based accommodation and tourism in Britain. Journal of Rural Studies 5 (3) 257-266.

Evans, N. and llbery, B. (1996) Exploring the influence of farm-based pluriactivity on gender relations in capitalist agriculture. Sociologia Ruralis 36 (1) pp. 74-92.

Evans, N., Morris, C. and Winter, M. (2002) Conceptualising agriculture: a critique of postproductivism as the new orthodoxy. Progress in Human Geography 26 (3) pp. 313-332.

Gasson, R. (1973) The goals and values of farmers. Journal of Agricultural Economics 24 (3) pp. 521-542.

Gasson, R. (1990) The Hidden Workforce: A Survey of the Spouse's Contribution to the Family Farm Business. Report prepared for the Women's Farm and Garden Association, Department of Agricultural Economics, Wye College, University of London.

Gasson, R. (1992) Farmer's wives - their contribution to the farm business. Journal of Agricultural Economics 43 (1) pp. 74-87.

Gasson, R. and Errington, A. (1993) The Farm Family Business (Wallingford: CAB International).

Gasson, R., Crow, G., Errington, A., Hutson, J., Marsden, T. and Winter, M. (1988) The farm as a family business: a review. Journal of Agricultural Economics 39 (1) pp. 1-41.

Grace, M. and Lennie, J. (1998) Constructing and reconstructing rural women in Australia: the politics of change, diversity and identity. Sociologia Ruralis 38 (3) pp. 351-370.

Gray, J. (1998) Family farms in the Scottish Borders: a practical definition by hill sheep farmers. Journal of Rural Studies 14 (3) pp. 341-356.

Hawton, K., Simkin, S., Malmberg, A., Fagg, J. and Harris, L. (1998) Methods used for suicide by farmers in England and Wales. British Journal Of Psychiatry 173 (Oct) pp. 320-324.

Heather, B., Skillen, L., Young, J and Vladicka, T. (2005) Women's gendered identities and the restructuring of rural Alberta. Sociologia Ruralis 45 (1) pp. 86-96.

Hughes, A., Morris, C. and Seymour, S. eds (2000) Ethnography and Rural Research (Cheltenham: Countryside Community Press).

Johnsen, S. (2004) The redefinition of family farming: agricultural restructuring and farm adjustment in Waihemo, New Zealand. Journal of Rural Studies 20 (4) pp. 419-432.

Kelly, S. and Bunting, J. (1998) Trends in suicide in England and Wales, 1982-86. Population Trends 92 (Summer) pp. 29-41.

Kelly, S., Charlton, J. and Jenkins, R. (1995) Suicidal deaths in England and Wales, 1982-92, the contribution of occupation and geography. Population Trends 80 (Summer) pp. 16-25.

Little, J. (2003) 'Riding the rural love train': heterosexuality and the rural community. Sociologia Ruralis 43 (4) 401-418.

Little, J. and Austin, P. (1996) Women and the rural idyll. Journal of Rural Studies 12 (2) 101 111. 
Little, J. and Panelli, R. (2003) Gender research in rural geography. Gender, Place and Culture 10 (3) pp. 281-189.

Lobley, M. and Potter, C. (2004) Agricultural change and restructuring: recent evidence from a survey of agricultural households in England. Journal of Rural Studies 20 (4) pp. 499-510.

Mackenzie, F. (1980) Women's place, women's space. Area 12 (1) pp. 47-51.

Mackenzie, F. (1992a) The politics of partnerships: farmwomen and farm land, Ontario. Pp. 85-96 in I. Bowler, C. Bryant and D. Nellis eds Contemporary Rural Systems in Transition, Volume. 2 (Wallingford: CAB International).

Mackenzie, F. (1992b) The worse it got, the more we laughed: a discourse of resistance among farmers of Eastern Ontario. Environment and Planning D: Society and Space 10 (6) pp. 691-713.

Mackenzie, F. (1994) Is where I sit, where I stand? The Ontario farm women's network, politics and difference. Journal of Rural Studies 10 (2) pp. 101-115.

Marsden, T. (1984) Capitalist farming and the farm family: a case study. Sociology 18 (2) pp. 203-224.

Marsden, T., Munton, R., Whatmore, S. and Little, J. (1986) Towards a political economy of capitalist agriculture: a British perspective. International Journal of Urban and Regional Research 10 (4) pp. 498-521.

Marsden, T., Munton, T., Ward, N. and Whatmore, S. (1996) Agricultural geography and the political economy approach: a review. Economic Geography 72 (4) pp. 361-376.

McDowell, L. (1999) Gender, Identity and Place (Oxford: Polity Press).

Meert, H., Van Huylenbroeck, G., Vernimmen, T., Bourgeois, M. and van Hecke, E. (2005)

Farm household survival strategies and diversification on marginal farms. Journal of Rural Studies 21 (1) pp. 81-97.

Monk, A. (2002) The role of British farm women in the new millenium. Rural Management and Human Resources 10, 1-11.

Morris, C. and Evans, N. (1999) Research on the geography of agricultural change: redundant or revitalized? Area 31 (4) pp. 349-358.

Morris, C. and Evans, N. (2001) Cheesemakers are always women: gendered representations of farm life in the agricultural press. Gender, Place and Culture 8 (4) pp. 375390.

Morris, C. and Evans, N. (2004) Agricultural turns: retrospect and prospect. Journal of Rural Studies 20 (1) pp. 95-111.

National Assembly for Wales (2003) Farming for the Future.

www.wales.gov.uk/keypubconsultation

Ni Laoire, C. (2000) Life histories and the study of rural youth migration. Pp.81-94 in A. Hughes, C. Morris and S. Seymour eds Ethnography and Rural Research (Cheltenham: Countryside Community Press).

Parsons, S. (2001) Women and rural enterprise. Journal of the Royal Agricultural Society of England 162 pp. 47-57.

Pettersen, L. and Solbakken, H. (1998) Empowerment as a strategy for change for farm women in Western industrialized countries. Sociologia Ruralis 38 (3) pp. 318-331. 
Pile, S. (1991) 'A load of bloody idiots'. Somerset dairy farmers' view of their political world. Political Geography Quarterly 10 (4) pp. 405-421.

Potter, C. and Tilzey, C. (2005) Agricultural policy discourses in the European post-Fordist transition: neoliberalism, neomercantisism and multifunctionality, Progress in Human Geography 29 (5) pp. 581-600.

Price, L. (2004) Stress in agriculture: the patriarchal way of life of farm families in Powys. Unpublished PhD thesis, Geography Department, University of Worcester.

Price, L. and Evans, N. (2005) Work and worry: farm women's way of life. Pp.45-60 in J. Little and C. Morris eds Critical Studies in Rural Gender Issues (Aldershot: Ashgate).

Roche, M. (2005) Rural geography: a borderland revisited. Progress in Human Geography 29 (3) pp. 299-303.

Shortall, S. (2002) Gendered agricultural and rural restructuring: a case study of Northern Ireland. Sociologia Ruralis 42 (2) pp. 160-175.

Scott, S. (1993) History and Herstory: engendered memories and experiences among Eastern Kentucky agriculturalist. Paper presented at the meeting of the Appalachians Studies Association, Johnson City, USA.

Scott, S. (1996) Drudges, helpers and team players: oral historical accounts of farm work in Appalachian Kentucky. Rural Sociology 61 (2) pp. 209-222.

Teather, E. (1994) The social and political organisation of rural women. Pp.31-49 in S. Whatmore T. Marsden and P. Lowe eds Gender and Rurality (London: David Fulton).

Scott, A., Christie, M. and Midmore, P. (2004) Impact of the 2001 Foot and Mouth Disease in Britain: implications for rural studies. Journal of Rural Studies 20 (1) pp. 1-14.

Walford, N. (2003) Productivism is allegedly dead, long live productivism. Evidence of continued productivist attitudes and decision-making in South-East England. Journal of Rural Studies 19 (4) pp. 491-502.

Wallace, C., Abbott, P. and Lankshear, G. (1996) Women farmers in South-West England. Journal of Gender Studies 5 (1) pp. 49-61.

Welsh Agricultural Statistics (1999) Crown Copyright.

Whatmore, S. (1991a) Farming Women: Gender, Work and the Family Enterprise (London: Macmillan).

Whatmore, S. (1991b) Life cycle or patriarchy? Gender divisions in family farming. Journal of Rural Studies 7 (1-2) pp. 71-76.

Winter, M. (2005) Geographies of food: agro-food geographies - food, nature, farmers and agency. Progress in Human Geography 29 (5) pp. 609-617. 